\title{
The Nabucco Project within Context of Energy Supply Security and International Politics
}

\author{
Gökhan Özkan, Yalova University
}

\begin{abstract}
The Nabucco Project is a project, which aims to transport rich natural gas resources of the Central Asia, the Caucasus and the Middle East to the European market via Turkey. In this study, the Nabucco Project was evaluated within context of the energy supply security concept and international politics. Firstly, interdependence between national power and energy supply security was investigated. How oil and natural gas became strategic raw materials of world politics beyond being primary energy resources of the global economy was examined. It was found that discovery of rich oil and natural gas resources in the Central Asia and the Caucasus after the Cold War turned the region into a focus of interest of the global and regional actors. In this connection, perspectives of the global and regional actors about the Nabucco Project were examined.As a result of analyses and evaluations, it was concluded that the Nabucco Project is a project that can significantly enhance Turkey's geopolitical importance and make Turkey one of the key countries of the east-west energy corridor.
\end{abstract}

JEL Codes: F50, F59, Q34

\section{Introduction}

According to forecasts for global energy consumption, natural gas and oil consumption will continue to increase in the next twenty years. It is estimated that global oil consumption will increase one percent and global natural gas consumption will increase 1,5 percent on average per year so that total increase in energy demand will amount to 45 percent by 2030. (IEA, 2009) Growing energy demand and its economic and political consequences make the energy supply security a more pronounced concept each and every day.

Energy supply security, which is defined as "continuous and stable supply of energy from reliable and different sources in sufficient amounts, at reasonable price and via reliable means of transport", became a priority for the developing and developed countries. The energy supply security became more important for international system dynamics after economic parameters became as important as political and military parameters in the $21^{\text {st }}$ century security perceptions. (Demiray and İşcan, 2008)

Growing importance of energy in world politics multiplied the geopolitical importance of countries and regions rich in hydrocarbon reserves. After the end of the Cold War and the dissolution of the Soviet Union, many countries gained independence in the Central Asia and the Caucasia. Rich hydrocarbon resources in this geography led to competition among the regional and global actors that want to shape the region according to their interests, which led to evaluations that "new great game" started in the region. It is argued that main actors of this "new great game" are Turkey, Russia, Iran, China, Afghanistan and Pakistan as regional powers and the U.S., the E.U. and Japan as global actors. (Amineh and Houweling, 2005)

As energy security and national security became interconnected, the Middle East and the Eurasia, where around 70 percent of the proved oil and natural gas reserves of the world are located became, in Brzezinski's words, the chessboard of the "new great game". Rivalry in the region intensified over the exploitation of these resources as well as the routes these resources will be transported to international markets.

Various projects were developed to transport these resources to international markets. Regional and global actors struggled to realize the pipeline project that is most suitable for their national interests. The Nabucco Project, which will transport the natural gas of the Middle East and the Caspian Region when completed, is one of the most important projects. In this 
study, the Nabucco Project will be evaluated within context of the energy supply security and "the new great game".

\section{Power, Energy Supply Security and the International System}

Energy supply security became one of the most important factors of international power struggles especially after the cut of energy supply was reflected to the international economic and political system as a major shock during the 1973 oil crisis. Regional and global actors of the international system struggle to control both the geography where these resources are located, the exploitation of these resources and the routes that these resources are transported to international markets to enhance their energy supply security. In this connection, oil and natural gas are not simple commodities that are exchanged at international markets. These resources and the geography these resources are located became strategic assets. (Amineh and Houweling, 2005)

It is argued that after the dissolution of the Soviet Union and after the hydrocarbon-rich Central Asian and the Caucasian states gained independence, the Caspian Region became a special focus of the regional and global actors and the "new great game" started in the region. (Dhaka, 2009) Brzezinski (1997) likened the region to a chessboard, on which regional and global actors struggle to protect their geostrategic and economic interests. The importance of the Eurasia increases along with the transformation process of the international system from a unipolar system with the US as the only superpower into a multipolar system with the EU, Russia and China as potential global powers and Turkey and Brazil as regional powers that enhance their global capabilities. (Arıboğan and Bilgin, 2009)

The Eurasian energy geopolitics is defined as the influence, power, and hegemony struggle for the oil and natural gas in the Central Asia and the Caucasus. (Edwards, 2003) It is argued that the West and Russia compete for the control of the hydrocarbon reserves and the export infrastructure in the region. It is argued that the West and Russia struggle to fill the Nabucco and South Stream Pipelines by the Azerbaijan and Turkmenistan natural gas. (German, 2009)

The Middle East and the Eurasia are the richest regions of the world in terms of natural gas and oil. These regions have almost seventy percent of the world oil and natural gas reserves. Turkey's geographic location makes it a natural energy bridge between the Middle East plus the Eurasia, where almost 70 percent of all oil and gas reserves are located, and the European Union countries, some of which have the highest per capita energy consumption levels in the world. (Bozhilova, 2009) Turkey is aware of the importance of its geographic location and uses its geostrategic advantage to be an energy hub. (Saivertz, 2009)

The EU, because of its growing natural gas needs, supports projects that aim to transport the Middle Eastern and Caspian Region natural gas and oil to the EU bypassing Russia such as the Baku-Tiflis-Ceyhan (BTC), Baku-Tiflis-Erzurum (BTE) and the Nabucco. These projects can make Turkey one of the key countries of the east-west energy corridor. In the next section, maybe the most important one of these projects, the Nabucco Project will be evaluated.

\section{The Nabucco Project}

Nabucco is a project that aims to transport the Central Asian, Caucasian and the Middle Eastern natural gas to Europe via Turkey and the Balkans. Since the Nabucco Project aims to diminish the energy dependence of the EU on Russia, it is supported both by the EU and the US. According to Mihail Delyagin, the President of the Russian Global Issues Institute, the Nabucco Project is the US's geopolitical project. Delyagin argues that the US broke off the Caucasia from Russia in terms of strategic relationship by the BTC Pipeline and may be aiming to break off Turkmenistan, Uzbekistan and Kazakhstan by the Nabucco Project. (Özbay, 2009)

One of the main pillars of the EU's policy of diversifying the supplier countries and pipeline routes is the Nabucco Project. If realized, it will be an important step for the EU towards 
diversifying supplier countries and the energy routes. The EU provided financial funds for the Nabucco Project for the first time in the beginning of 2009. In the same year, the Nabucco Intergovernmental Agreement was signed by Turkey and the four European countries (Austria, Hungary, Romania, and Bulgaria). If the Nabucco Project is realized, the EU will have successfully applied its strategy to diversify supplier countries and routes. The EU will be able to provide natural gas from energy routes that pass from the territories of countries other than Russia and will decrease its dependence on Russia.

The Nabucco Project is a project that will enhance Turkey's geopolitical importance as well as lowering the EU's energy dependence on Russia. If the Project is realized, Turkey will be one of the key countries of the east-west corridor. At the same time, the Nabucco Project is a very important project for Turkey, which because of cuts of natural gas supplies from Iran and Russia, wants to diversify the energy supplier countries and the routes by reaching the Middle Eastern and the Caspian Region natural gas.

The Nabucco Project is seen as one of the main pillars of the "new great game". Regional and global actors have different perspectives about the Project parallel to their regional interests and policies as will be analyzed in the next section.

\subsection{Russia}

Russia, the richest country in terms of natural gas reserves, owns 26,6 percent of all the natural gas reserves in the world. Russia is also one of the richest countries in terms of coal and oil reserves. Russia's natural resources made it one of the most important players in the global energy market. As the oil demand and price rose in the last 10-20 years as a consequence of the fast economic growth of the developing countries such as China and India; as energy supply security became a priority for both the developed and developing countries and as the instabilities in the Middle East increased uncertainty; Russia's leverage as one of the richest countries in terms of energy resources grew. It is argued that Russia used this leverage to increase its declining influence after the Cold War and became an energy superpower. (Sevastyanov, 2008)

It is argued that Russia tries to be a monopoly not only on the transportation of its own the hydrocarbon resources but also on the transportation of the hydrocarbon resources of the Caspian Region by using its geostrategic location. (Blank, 2008) It is argued that Russia tries to increase its influence on the Central Asian and the Caucasian countries parallel to its "Near Abroad" policy by using the critical energy infrastructure. Because of this, Russia opposes the western countries' efforts to bypass Russia by linking the supplier countries in the Caspian Region to the Europe via Azerbaijan and Turkey. (Rywkin, 2008)

It is argued that the military clashes between Georgia and Russia should be evaluated within this context. The clashes are evaluated as an example of the differentiation of the security perceptions of the West and Russia since the end of the Cold War. (Alexandrova-Arbatova, 2009) The balance of power in the Caucasus changed substantially after the clashes. (Ekşi, 2009) Further than that, Pabst (2009) argues that the clashes of August 2008 strengthened the movement of balance of power towards east, which started after the global financial crisis.

It is argued that the clashes may affect the pipeline projects supported by the US in the region such as the Nabucco Project negatively. (Cheterian, 2009) It is argued that Russia's objective is to hold the control of the strategic energy export infrastructure rather than to protect its citizens in the South Osetia. (German, 2009) The US authorities criticized the clashes by stating that they perceive them as Russia's efforts to divide Georgia and undermine the South Energy Corridor. (Fried, 2008) In a report prepared by the European Commission, it is stated that the incidents in Georgia show that these are critical times for energy security and the EU should intensify its efforts with regards to energy supply security. (Commission of the European Communities, 2008)

It is argued that since Russia is opposed to the Nabucco Project, which aims to transport the 
Caspian natural gas to Europe bypassing the Russia route, it developed the alternative South Stream Project. (Larrabee, 2009) With this project, the natural gas of the region will be transported to Europe via Russia and the Black Sea bypassing Azerbaijan and Turkey.

\subsection{The United States}

The US, which became the only superpower in the international system after the end of the Cold War, wants to increase its influence over the energy resources to sustain its superpower status. Discovery of oil and natural gas reserves in the Central Asia and the Caucasus caught the attention of the US like other regional and global actors and the US defined the region as strategically vital. The US tried to protect the interests of the powerful energy companies; meanwhile its policies had also a power politics dimension. (Tsantoulis, 2009) The exploitation of the Caspian Region natural gas and oil and the infrastructure to transport these resources became the focus of the US's security policy in the region. (McDermott, 2008)

In the post-Cold War period, control of the Eurasian Heartland, as defined by Mackinder, became one of the priorities of the US foreign policy. (Labban, 2009) It is argued that the US's objective is not only to control the energy resources in the region but also to contain its potential rivals such as China and Russia. (İşeri, 2009) China's increasing influence in the Central Asia is evaluated as one of the issues that the US must be careful about. (Rywkin, 2008)

The US wants the transportation of the region oil and natural gas via the routes that pass over the territories other than the Russia's. In this way, the US tries to diminish Russia's influence in the region. (Larrabee, 2009) The US also tries to prevent Iran, with which it has disagreements over the nuclear energy, from becoming a transit country. In this connection, the US is opposed to Iran's participation in the pipeline projects such as the Nabucco. So, it is argued that the optimal pipeline route for US's strategy is the Azerbaijan-Georgia-Turkey-Europe route and because of this, the US is the strongest supporter of the BTC, BTE and the Nabucco Projects.

\subsection{Iran}

It is expected that the geostrategic importance of Iran, which has the richest natural gas reserves after Russia and which is the second richest country in terms of oil reserves, will increase rapidly in the global energy geopolitics if it can benefit from its natural reserves effectively. (Coşkun, 2009) Nonetheless, because of its technological backwardness and its international disputes with other countries, it faces many obstacles at both exploiting and distributing these resources.

Disagreement among Iran, the US and the EU about nuclear energy restricts cooperation opportunities among these countries with regards to the exploitation and transportation of Iran's natural resources. Iran, which can contribute to the Nabucco Project substantially, is not included in the Project because of the US's political reservations.

Nonetheless, Turkey signed with Iran the "Natural Gas Memorandum of Understanding (MoU)" in 2008 to develop its relations with its neigbour and to diminish its energy dependence on Russia. According to the MoU, a $2000 \mathrm{~km}$. pipeline from Iran's Assaluyeh Region to the Turkish border will be constructed and connected to the pipeline on the Turkish side.

The MoU is important especially with regards to the Nabucco Project. If realized, the transportation of the Iran gas to Europe with the Nabucco Pipeline will be possible. Also, it will be possible to transport the Turkmen gas, which cannot be included in the Nabucco Project because of the uncertainties about the legal status of the Caspian Sea, over the Iranian territories to Turkey. In this way, it will be possible to include the Turkmen gas to the Nabucco Project. It is also estimated that negotiations about the legal status of the Caspian Sea can also go forward if the Turkmen gas was included in the Nabucco Project. 


\subsection{China}

One of the most important players of the new great game in the Central Asia and the Caucasus is China, average economic growth rate of which surpassed eight percent in the last two decades. China makes investments all over the world to provide the energy it needs for its fast growing economy. According to International Energy Agency's forecasts, China's oil demand will surpass 10 million barrels per day by 2020. Since China's resources are not sufficient to meet this demand, it is expected that China will import 80 percent of its energy needs. The Caspian Region, because of its proximity, is seen as a good alternative to meet China's energy demand and because of this China has made big investments in the region. (Ong, 2009)

Chin has developed various projects to exploit and transport the rich natural reserves of the region. The Turkmenistan-Uzbekistan-Kazakhstan-China Natural Gas Pipeline Project, which was developed to transport the Turkmen gas to China, was realized and the first Turkmen gas reached Beijing in February 2010. The transportation of the Uzbek and Kazakh gas on this pipeline is also considered. It is argued that China, taking into account the US preponderance in the high seas, is developing a project that will link the Iranian natural gas and oil to the China-Kazakhstan Pipeline to increase its energy security.

\subsection{The European Union}

Since the EU is a relatively poor region in terms of natural gas reserves and must import most of the natural gas it needs, energy security became a priority for the EU. It imports around 50 percent of the natural gas it needs and around 80 percent of this natural gas is imported from three countries, Russia, Norway and Algeria. The natural gas and oil reserves in the Central Asia and the Caucasus created an alternative for the EU, which tries to diversify the supplier countries and diminish its energy dependence on these countries, particularly Russia. It is argued that the EU's regional policies depend on constituting an energy export infrastructure that bypasses Russia with the support of the US.

The cut of the natural gas supplies from Russia to Europe in 2006 because of the price disagreement between Russia and Ukraine and the recurrence of this problem in the following years directed the EU to take new measures about energy security. One of the biggest steps the EU took was increasing its support for the Nabucco Project and signing of the Nabucco Agreement in July, 2009. It is argued that the military clashes between Russia and Georgia in 2008 and the recurrence of the energy crisis between Russia and Ukraine in 2009 increased the Nabucco Project's momentum. After the energy crisis between Russia and Ukraine in 2009, the EU declared that energy security became a priority.

\section{The Nabucco Project and Turkey}

The geostrategic location of Turkey between the Central Asia, Caucasus and Middle East Regions rich in hydrocarbon reserves and the EU, which is expected to import 75 percent of the energy it consumes by 2020, makes Turkey one of the key countries of the east-west energy corridor and one of the most important actors of the new great game in the region.

The EU decided to take new measures about energy security after the EU's energy dependence on Russia rose and after the problems between Russia and the transit countries repeated and disrupted the European economy. In this connection, Turkey became a key country with respect to transportation of the hydrocarbon resorces of the Middle East and the Caspian Region to Europe via routes that bypass Russia. This intensified the competition between Turkey and Russia as can be seen at the opposition of Russia to the BTC Project. (Öniş and Yilmaz, 2009)

It is argued that the Nabucco Project may lower Russia's role in transporting hydrocarbon resources of the Caspian Region to Europe as the BTC did. If the Nabucco is realized, Turkey will be able to play the energy bridge role by transporting not only the Caspian Region natural 
gas but also the Middle Eastern and the African natural gas.

Pipelines such as the Nabucco, BTC, BTE; while making Turkey an energy corridor and increasing Turkey's geopolitical importance, also increase Turkey's energy supply security. Turkey, similar to the EU countries, is dependent on other countries with respect to energy and it is estimated that its dependence will increase. In this connection, Turkey also follows the policy of diversifying its energy resources, energy supplier countries and the routes.

It is argued that if Turkey becomes one of the key countries in the east-west corridor and if it becomes a strategic country for the EU's energy supply security, Turkey's EU membership negotiations may proceed more positively. (Tekin and Williams, 2009)

\section{Conclusion}

Turkey's unique geostrategic location makes it a Middle Eastern, European and Eurasian country at the same time, which increases Turkey's potential to be one of the key countries of the east-west and south-north energy corridors. Turkey, if it uses its geostrategic leverage to find solutions for the regional problems and to provide stability by using diplomacy and developing new projects, can consolidate its regional power and increase its weight in world politics.

It is argued that Turkey should follow proactive rather than reactive policies while taking into account the strategies of the regional and global actors in the new great game. Turkey can become one of the key countries of both the east-west and north-south energy corridors if it utilizes its geostrategic location in the Middle East and the Caspian Region, which is home to around 70 percent of all proven natural gas and oil reserves of the world.

Maybe the most important project of the east-west energy corridor is the Nabucco Project. If it is realized, Turkey will be one of the key countries for the transportation of not only the Central Asian and Caucasian natural gas, but also the Middle Eastern and African gas. Since energy security became a priority for the EU, Turkey's geostrategic importance for the EU will also increase, Turkey's EU membership negotiations will proceed more positively and Turkey will have hosted the alliance of civilizations at the energy dimension.

\section{References}

- Amineh and Houweling, 2005. "Caspian Energy: Oil and Gas Resources and the Global Market”, in Central Eurasia in Global Politics: Conflict, Security and Development. (eds. Parvizi Amineh ve Henk Housweling) Koninklijke Brill NV, Leiden, p. 82.

- Alexandrova-Arbatova, 2009. "The Impact of the Caucasus Crisis on Regional and European Security", Southeast European and Black Sea Studies, 9 (3), p. 287.

- Arıboğan and Bilgin, 2009. "Yeni Enerji Düzeni Siyaseti (Neopolitik): Jeopolitik’ten Enerjeopolitik'e”, Uluslararası İlişkiler 5 (20) (Özel Sayı: Enerji), p. 109-132.

- Blank, 2008. "What Comes After the Russo-Georgian War? What's at Stake in the CIS”, American Foreign Policy Interests, 30 (6), p. 379-391.

- Bozhilova, 2009. "Energy Security and Regional Cooperation in South-East Europe", Journal of Balkan and Near Eastern Studies, 11 (3), p. 293-311.

- Brzezinski, 1997. The Grand Chessboard: American Primacy and Its Geostrategic Imperatives. Basic Books, New York, s. 30-56.

- Cheterian, 2009. "The August 2008 War in Georgia: From Ethnic Conflict to Border Wars", Central Asian Survey, 28 (2), p. 164.

- Commission of the European Communities, 2008. Green Paper: Towards a Secure, Sustainable and Competitive European Energy Network. Commission of the 
European Communities, Brussels, p. 3.

- C Coşkun, 2009. “Küresel Enerji Jeopolitiği ve İran”, Uluslararası_lilişkiler, 5 (20) (Özel Sayı: Enerji), p. 179-201.

- Demiray and İşcan, 2008. "Uluslararası Sistemde Güvenlik Kavramının Değişimi Ekonomik ve Jeopolitik Arka Planı”, Dumlupınar_Üniversitesi_Sosyal_Bilimler Dergisi, 21, p. 161.

- Dhaka, 2009. "The Geopolitics of Energy Security and the Response to its Challenges by India and Germany", Geopolitics, 14 (2), p. 279.

- Edwards, 2003. "The New Great Game and the New Great Gamers: Disciples of Kipling and Mackinder", Central Asian Survey, 22 (1), p. 83.

- Ekşi, 2009. "Türkiye-Azerbaycan İlişkileri: Söylemden Reelpolitiğe”, Avrasya Etüdleri, 36, p. 110.

- Fried, 2008. "US-Russia Relations in th Aftermath of the Georgia Crisis", Testimony of Daniel Fried, Assistant Secretary of State for European and Eurasian Affairs, before the House Committee on Foreign Affairs, Washington DC, 9 September 2008. http://www.state.gov/p/eur/rls/rm/109363.htm.

- International Energy Agency (IEA), 2009. World Energy Outlook 2009: Executive Summary. IEA, Paris, p. 3.

- İşeri, 2009. "The US Grand Strategy and the Eurasian Heartland in the Twenty-First Century", Geopolitics, 14 (1), p. 27.

- Labban, 2009. "The Struggle for the Heartland: Hybrid Geopolitics in the Transcaspian", Geopolitics, 14 (1), p. 2.

- Larrabee, 2009. "The United States and Security in the Black Sea Region", Southeast European and Black Sea Studies, 9 (3), p. 305.

- McDermott, 2008. "United States and NATO Military Cooperation with Kazakhstan: The Need for a New Approach", The Journal of Slavic Military Studies, 21 (4), p. 616.

- Ong, 2009. "China's Strategic Convergence with Russia", Korean Journal of Defense Analysis, 21 (3), p. 319.

- Öniş and Yılmaz, 2009. "Between Europeanization and Euro-Asianism: Foreign Policy Activism in Turkey during the AKP Era”, Turkish Studies, 10 (1), p. 10.

• Özbay, 2009. "Nabucco'nun Fendi Güney Akım'1 Yendi mi?”, http://www.bilgesam.org/tr/index.php? view $=$ article \&catid=131\%3Aenerji\&id=398\%3Anabucconun-fendi-guney-akimiyendi mi\&format $=$ pdf\&option $=$ com_content $\&$ Itemid $=146$

- Pabst, 2009. "Central Eurasia in the Emerging Global Balance of Power", American Foreign Policy Interests, 31 (3), p. 166.

- Rywkin, 2008. "Russia's Place in the World", American Foreign Policy Interests, 30 (5), p. 311.

- Sevastyanov, 2008. "The More Assertive and Pragmatic New Energy Policy in Putin's Russia: Security Implications for Northeast Asia”, East Asia, 25, p. 35-55.

- Tekin and Williams, 2009. "EU-Russian Relations and Turkey's Role as an Energy Corridor", Europe-Asia Studies, 61 (2), p. 352.

- Tsantoulis, 2009. "Geopolitics, (Sub)regionalism, Discourse and a Troubled 'Power Triangle' in the Black Sea”, Southeast European and Black Sea Studies, 9 (3), p. 249. 